Open Access to Pharmaceutical and Medical Research

(C) 2011-18, publisher and licensee JDDT, This is an Open Access article which permits unrestricted non-commercial use, provided the original work is properly cited

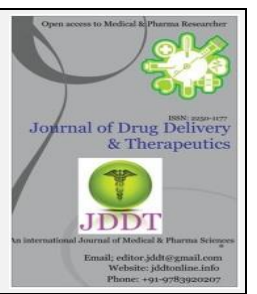

Open $\mathcal{O}_{\text {Access }}$

Research Article

\title{
Primary Metabolites Profiling of Vetiveria Lawsonii from Leaf and Root
}

\author{
Anuradha Gauttam ${ }^{1}$, Nakuleshwer Dutt Jasuja ${ }^{1}$ and Rakesh Kumar ${ }^{2}$ \\ ${ }^{1}$ Department of Agriculture, Vivekanand Global University Jaipur, Rajasthan, India \\ 2 Department of Biochemistry, Mewar University Chittorgarh, Rajasthan, India
}

\begin{abstract}
Various traditional systems of medicine enlightened the importance of Indian plants to have a great medicinal value. The present study was aimed to evaluate the Primary Metabolites study of Vetiveria lawsonii, belong to Poaceae family. Extracts were prepared in methanol, ethanol by Soxhlet extraction. Quantitative extraction of preliminary phytochemicals investigation revealed the presence of Carbohydrates (Starch and Total Soluble Sugar), Lipid, Proteins, and Phenol by using UV spectrometer. Experimental medicinal plant Vetiveria lawsonii are showing high concentration of primary metabolites. Hence, we can conclude that the methanol and ethanol extracts of Vetiveria lawsonii was possess primary metabolites.
\end{abstract}

Keywords: - Vetiveria lawsonii; Primary Metabolites.

Article Info: Received 11 July 2019; Review Completed 21 Aug 2019; Accepted 26 Aug $2019 ; \quad$ Available online 30 Aug 2019

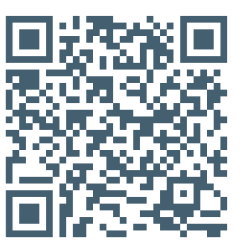

Cite this article as:

Gauttam A, Jasuja ND, Kumar R, Primary Metabolites Profiling of Vetiveria Lawsonii from Leaf and Root, Journal of Drug Delivery and Therapeutics. 2019; 9(4-A):373-375 http://dx.doi.org/10.22270/jddt.v9i4-A.3497

*Address for Correspondence:

Anuradha Gauttam, Department of Agriculture, Vivekanand Global University Jaipur, Rajasthan, India

\section{INTRODUCTION}

From the pre-historic time, the Indian medicinal plants have been used in Siddha, Ayurveda and Unani. The plants from Poaceae family are having high medicinal values (Ramachandran and Elezabeth, 2014). Many medicinal plants are used in modern ayurvedic medicine in Ayurveda, where they occupy a very significance place as raw material for important drugs and plants used in traditional system of medicine in pharmaceutical houses are collected from wild sources (Sani A. 2007). Vetiveria lawsonii is an Indian plant belongs to the family Poaceae. The plants of Poaceae family are used as analgesic, antibacterial, antiperspirant/ deodorants, astringent, depurative, digestive, emmenagogue, galactagogue, insect repellents and skin tonic. The literature review revealed that there is no documentation of scientific work on Vetiveria lawsonii. An attempt has been made to evaluate the antimicrobial activity of this plant (Alagesaboopathi C. 2011; Harborne JB. 1973; Muhit M., et al., 2010).

The valuable medicinal properties of different plants are due to the presence of several natural compounds and antioxidants: enzymatic and non-enzymatic (Starlin T, et al., (2012). Currently, the synthetic antioxidants might be unsafe and its toxicity has been criticized. It is generally assumed that frequent use of plant-derived phytochemicals may contribute to shift the stability in the direction of a sufficient antioxidant status. As a result, attention in natural antioxidants, in particular, plant origin, has deeply amplified in recent years (Ramkumar S, et al., (2015).

Experimental plant Vetiveria lawsonii is considered as a renowned folk medicine used against diseases and infections like: arthritis, rheumatic pains, respiratory problems, wounds, urinary infections, dysentery and also aphrodisiac. Stem, leaves, and roots are reported to possess hydrocyanic acid and delphinidin. Several flavonoids such as cyanidins are reported in the leaves (Sowmya S, et al., (2015). Infusion of seeds along with extract of tubers is traditionally given orally to diabetic patients to check sugar level of blood. The whole plant is used in diuretics, tumors, neuralgia and splenopathy (Sumitra S, et al., (2012).

\section{Scientific classification}

$\begin{array}{ll}\text { Kingdom } & \text { : Plantae } \\ \text { Superdivision } & \text { : Spermatophyta } \\ \text { Division } & \text { : Magnoliophyta } \\ \text { Class } & \text { : Liliopsida } \\ \text { Subclass } & \text { : Commelinidae } \\ \text { Order } & \text { : Cyperales } \\ \text { Family } & \text { : Poaceae } \\ \text { Genus } & \text { : Vetiveria } \\ \text { Species } & \text { : lawasani }\end{array}$




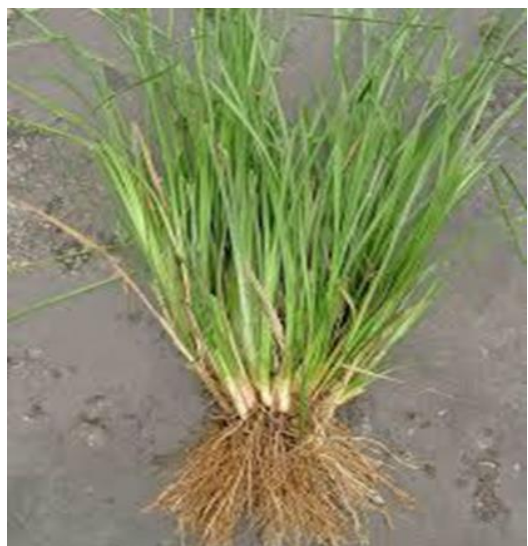

Vetiveria lawasani

\section{MATERIAL AND METHODS}

\section{Sample collection}

Leaf and root plant materials of Vetiveria lawasonii were collect from Sawaimadhopur District, Rajasthan, India and authenticated by Department of Botany, University of Rajasthan Jaipur Rajasthan. The plant materials (leaf and root) were collected, washed with distilled water and shade dried and make it powder form for further experiments.

\section{Quantitative Determination of Primary Metabolites}

Primary metabolites directly involved in growth and development while secondary metabolites are not involved directly and they have been worked as biocatalysts. Primary metabolites are of prime importance and essentially required for growth of plants. Many primary metabolites lie in their impact as precursors or pharmacologically active metabolites of pharmaceutical compounds such as antipsychotic drugs Jayaraman J., 1981; Bray HG and Thorpe WV. 1954).

\section{Carbohydrates}

\section{- Total soluble sugar:}

The total soluble sugar content was determined according to using the method of Mc Cready et al, (1950). 0.1grm of sample was crush with $5 \mathrm{ml} \mathrm{80 \%} \mathrm{ethanol} \mathrm{and} \mathrm{centrifuge} \mathrm{at}$ $10000 \mathrm{rpm}$ for 10 minutes, after centrifugation collect supernatant in a test tube added $5.0 \mathrm{ml}$ of sulphuric acid and $1 \mathrm{ml} 5 \%$ phenol than mix by vertex. Incubated in boiling water bath for 20 minutes, after which the absorbance was read at $490 \mathrm{~nm}$ against $80 \%$ ethanol reagent blank. The analysis was performed in triplicates and the results were expressed as $\mathrm{mg} / \mathrm{g}$ sample.

\section{- Starch:}

The starch content was determined according to using the method of (Loomis and Shull (1973) for total soluble sugar. After centrifuge total soluble sugar sample collect palate mix with $1 \mathrm{ml}$ perchloric acid $\left(\mathrm{HClO}_{4}\right)$ mixing by vertex now take $1 \mathrm{ml}$ sample in a test tube with $\mathrm{H}_{2} \mathrm{SO}_{4}$ added $1 \mathrm{ml} 5 \%$ phenol mixing by vertex keep 20 minutes at room temperature, after which the absorbance was read at $490 \mathrm{~nm}$ against $80 \%$ ethanol reagent blank. The analysis was performed in triplicates and the results were expressed as $\mathrm{mg} / \mathrm{g}$ sample.

\section{Proteins}

Protein content was determined according to the method of (Osborne, 1962) was followed. 0.1grm of sample was mixed with $3 \mathrm{ml} 10 \%$ TCA (trichloroacetic acid) than crush and centrifuge at $15000 \mathrm{rpm}$ for 10 minutes, now take plate add $1 \mathrm{ml} 5 \%$ TCA $\left(\mathrm{CCl}_{3} . \mathrm{COOH}\right)$ than mix it by vertex. Take $5 \mathrm{~m}$ alkaline solution in a test tube with $1 \mathrm{ml}$ Folin-Ciocalteau reagent and incubated again for 10 minutes at room temperature. Absorbance was read at $750 \mathrm{~nm}$ against $10 \%$ TCA as a reagent blank. The analysis was performed in triplicates and the results were expressed $\mathrm{mg} / \mathrm{g}$ sample.

\section{Lipids}

Lipid content was determined according to the method was followed (Jayaram, 1981). 0.3gm sample crush in $10 \mathrm{ml}$ distilled water, now $20 \mathrm{ml} \mathrm{CHCl} 3$ with $10 \mathrm{ml}$ methanol mix and leave it 20 minutes kept on room temperature, will filter it after $20 \mathrm{~min}$, added $20 \mathrm{ml} \mathrm{CHCl} 3$ with $2 \mathrm{ml}$ distilled water, mix properly, separate properly by separating faunal, collect lower layer and dry it in a petri plate, note blank and after dry weight of petri plate. The analysis was performed in triplicates and the results were expressed $\mathrm{mg} / \mathrm{g}$ sample.

\section{Phenols}

Total phenol content were estimated in the ethanolic extract by the procedure given by (Bray and Thorpe, 1954), Folin Ciocalteau method. To $0.2 \mathrm{gm}$ of sample crush in $4 \mathrm{ml} 80 \%$ ethanol, centrifuge it at 10000rpm for $10 \mathrm{~min}$,after centrifuge collect supernatant add $1 \mathrm{ml}$ Folin Ciocalteau reagent and incubated at room temperature for three minutes. After three minutes $2 \mathrm{ml}$ of $20 \% \mathrm{Na} 2 \mathrm{CO} 3$ was added, mixed well and incubated the tubes in boiling water bath for 1 minute. Cooled rapidly and read absorbance at 750 $\mathrm{nm}$ against reagent $80 \%$ ethanol blank. The analysis was performed in triplicates and the results were expressed as $\mathrm{mg} / \mathrm{g}$ sample.

\section{RESULTS \& DISCUSSION}

Primary metabolites results extracts of Vetiveria Lawsonii.

\begin{tabular}{|c|l|l|c|c|}
\hline \multirow{2}{*}{ Sr. No } & \multirow{2}{*}{ Primary metabolites } & \multicolumn{2}{|c|}{ Unit in mg/g dry weight } \\
\cline { 3 - 4 } & & Leaf & Root \\
\hline \multirow{2}{*}{1} & \multirow{2}{*}{ Carbohydrates } & Total soluble sugar & 1.75 & 1.81 \\
\cline { 3 - 4 } & & Starch & 1.75 & 2.25 \\
\hline 2 & Protein & 95.0 & 102.0 \\
\hline 3 & Lipid & 4.33 & 4.67 \\
\hline 4 & Phenol & 1.55 & 1.125 \\
\hline
\end{tabular}


Graphical presentation of primary metabolites extracts of Vetiveria Lawsonii.

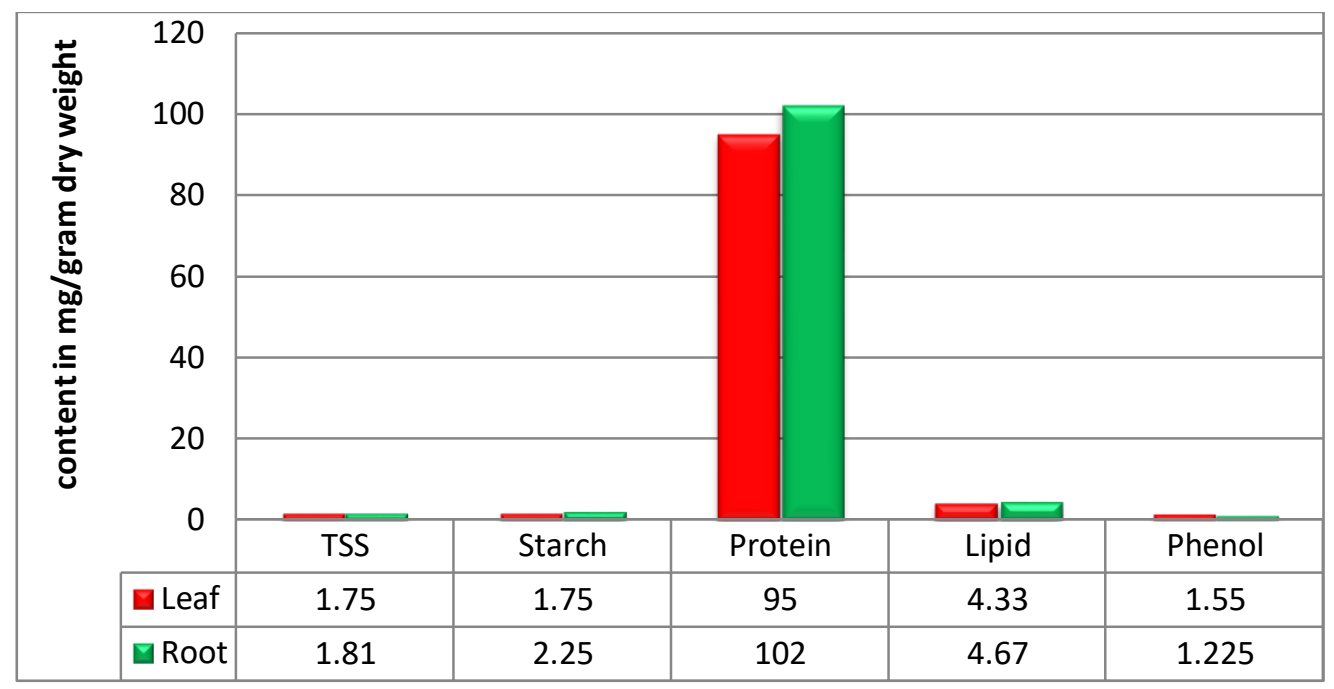

\section{CONCLUSION}

In the present study, quantitative analysis of primary metabolites profiling of root and leaves ethanolic extract of Vertivaria lawasonii was investigated. The extract was found to possess more primary metabolites activities, Based on the results it can be concluded that, the root and leaves ethanolic extract of Vertivaria lawasonii which contains high amount of primary metabolites. In future this plant extract are significant and valuable sources of natural compounds, which may be helpful in food supplements and used in pharmaceutical industry.

\section{ACKNOWLEDGEMENTS}

The authors are thankful to Chancellor, Registrar and HOD Department of Agriculture of Vivekanand Global University, Jaipur for providing facilities and encouragement.

\section{REFERENCES}

1. Alagesaboopathi C. antimicrobial screening of selected medicinal plants in Tamilnadu, India, African Journal of Microbiology Research, 2011; 5 (6),617-621.

2. Bray HG and Thorpe WV. analysis of phenolic compounds of interest in Metabolism, methods Biochem Anal. 1954;1:27-52.

3. Harborne JB. phytochemical methods, Chapman and Hall Ltd, London, 1973; 49-188.

4. Jayaraman J. Laboratory Manual in Biochemistry. New Delhi: Wiley Eastern Limited. 1981.

5. Loomis, W. I., \& Shull, C. A. A gas street method for measuring respiration. Methods in plant physiology, 1st edn, McGraw-Hill Book Co, New York, 1973; 101-103.

6. McCready, R. M., Guggolz, J., Silviera, V., \& Owens, H. S. Determination of starch and amylose in vegetables. Analytical chemistry, 1950; 22(9), 1156-1158.
7. Muhit Md Abdul, Apu Apurba Sarker, Islam Md Saiful, Ahmed Muniruddin. Cytotoxic and antimicrobial activity of the crude Extract of Abutilon Indicum, International Journal of Pharmacognosy and Phytochemical Research, 2010; 2(1), 1-4.

8. Osborne D. J. Effect of kinetin on protein \& nucleic acid metabolism in Xanthium leaves during senescence. Plant Physiology, 1962; 37(5), 595.

9. Sani Ali Audu, Ilyas Mohammed, Haruna Abdul Kaita. phytochemical screening of the leaves of Lophira lanceolata (Ochanaceae), Life science Journal, 4 (4), 2007, 75-79.

10. Sen A and Batra A, (2012); Evaluation of Antimicrobial Activity of Different Solvent Extracts of Medicinal Plant: Melia Azedarach L. Int J Curr Pharm Res, ISSN- 0975-7066, Vol 4, Issue 2, 67-73.

11. Ramachandran $P$ and Viji Saral Elezabeth. International Journal of Research in Pharmaceutical and Nano Sciences. 3(2), 2014, 101 - 104.

12. Starlin T, Ragavendran P, Raj CA, Perumal PC, Gopalakrishnan VK. (2012) Element and functional group analysis of Ichnocarpus frutescens R. Br. (Apocynaceae). Int J Pharm Pharm Sci 2012;4:343-5.

13. Ramkumar S, Perumal PC, Sudhakar G, Mandal AK, Mohankumar P, Suresh kumar PS, (2015) Isolation and characterization of Polyphenol oxidase from UPASI selected clone of Camellia sinensis (L.) O. Kuntze. Indo-Am J Pharm Res; 5:241-52.

14. Sowmya S, Perumal PC, Anusooriya P, Vidya B, Pratibha P, Gopalakrishnan VK. In vitro antioxidant activity, in vivo skin irritation studies and HPTLC analysis of Cayratia trifolia (L.) Domin. Int J Toxicol Pharm Res. 7:1-9.

15. Sumitra S, Rajinder M, Surendra KS. Phytochemical analysis and pharmacognostical standardization of stem of Cayratia trifolia (linn.) Domin. Int J Pharm Sci Res. 3:4503-6. 